\title{
A UPLC-MS/MS METHOD DEVELOPMENT AND VALIDATION FOR THE ESTIMATION OF POMALIDOMIDE FROM HUMAN PLASMA
}

\author{
D. ATUL VASANTH*a, B. RAJKAMAL \\ aMewar University, Gangrar, Chittorgarh 312901, Rajasthan, India, bKVK College of Pharmacy, Surmajiguda, Hyderabad 501512, \\ Telangana, India \\ Email: atulvasanth99@gmail.com
}

Received: 13 Oct 2016, Revised and Accepted: 05 Dec 2016

\begin{abstract}
Objective: The present work aimed to develop a simple, rapid, specific and precise liquid chromatography-tandem mass spectrophotometric (LCMS/MS) validated method for quantification of pomalidomide and internal standard (ISTD) Fluconazole in human plasma.

Methods: $50 \mu \mathrm{l}$ of $0.1 \%$ formic acid was added to plasma samples prior to liquid-liquid extraction (LLE) using $2.5 \mathrm{ml}$ of ethyl acetate. Chromatographic separation was achieved on Xterra, $\mathrm{RP}_{18}, 5 \mu(50 \times 4.6 \mathrm{~mm})$ column using a mixture of $0.1 \%$ (v/v) formic acid in water to methanol at a ratio of $12: 88, \mathrm{v} / \mathrm{v}$ as the mobile phase. The flow rate was $0.50 \mathrm{ml} / \mathrm{min}$. The LC eluent was split, and approximately $0.1 \mathrm{ml} / \mathrm{min}$ was introduced into Tandem mass spectrometer using turbo Ion Spray interface at $325^{\circ} \mathrm{C}$. Quantitation was performed by transitions of $m / z 260.1$ precursor ion to the $\mathrm{m} / \mathrm{z} 148.8$ for pomalidomide and $\mathrm{m} / \mathrm{z} 307.1 / 238.0$ for fluconazole.
\end{abstract}

Results: The concentrations of nine working standards showed linearity between 9.998 to $1009.650 \mathrm{ng} / \mathrm{ml}\left(r^{2} \geq 0.9968\right)$. Chromatographic separation was achieved within $2 \mathrm{~min}$. The average extraction recoveries of three quality control concentrations were $53.86 \%$ for pomalidomide and were within the acceptance limits. The coefficient of variation was $\leq 15 \%$ for intra-and inter-batch assays. The $\% \mathrm{CV}$ of ruggedness ranges 1.32 to 4.03 . The $\%$ stability of short term and long term stock solution stability studies was found to be $99.01 \%$ and $98.49 \%$ respectively.

Conclusion: The results obtained for specificity, linearity, accuracy, precision, ruggedness and stability studies were within limits. Thus the validated economical method was applied for pharmacokinetic studies of pomalidomide.

Keywords: Pomalidomide, LC-MS/MS, Human plasma, Liquid-liquid extraction

(C) 2016 The Authors. Published by Innovare Academic Sciences Pvt Ltd. This is an open access article under the CC BY license (http://creativecommons.org/licenses/by/4.0/)

DOI: http://dx.doi.org/10.22159/ijap.2017v9i1.15653

\section{INTRODUCTION}

Pomalidomide chemically 4-amino-2-(2, 6-dioxopiperidin-3-yl) isoindoline-1, 3-dione, the newest immune-modulatory drugs (IMiD), was designed to be more potent and less toxic than thalidomide and lenalidomide [1-2]. It is used for the treatment of relapsed and refractory multiple myeloma. Dr. Rober D'Amato's labs led to the first report [3-4] stating that 3-amino-thalidomide was able to directly inhibit both the tumor cell and vascular compartments of myeloma cancers. An HPLC-UV method was reported for inversion of pomalidomide in phosphatebuffered saline and human plasma in $\mu \mathrm{g} / \mathrm{ml}$ range [5]. The LC-MS methods were also published for the Pharmacokinetic study of pomalidomide but no validation details were presented [6-7]. A validated UPLC-MS method was reported using negative ionisation mode for determination of pomalidomide from rat plasma [8], Described here is a simple, sensitive, and selective LC-MS/MS method for pomalidomide in the human plasma concentration range of 9.998 to $1009.650 \mathrm{ng} / \mathrm{ml}$. As there is no literature on stability data of pomalidomide in human plasma, this study performed assay validations, according to the FDA guidelines [9]. While this method with validation details were economical and applied for pharmacokinetic studies of pomalidomide.

\section{MATERIALS AND METHODS [8]}

\section{Apparatus and software}

The HPLC pump (Agilent 1200 series Binary SL) with an autosampler (Agilent 1200 series Hip-ALSSL) was coupled with Agilent 6460 Triple Quad Tandem mass spectrometer. The column oven was Agilent 1200 series TCC SL. The chromatographic integration was performed by Agilent mass hunter software.

\section{Chemicals and reagents}

Pomalidomide and Fluconazole (IS) were procured from NATCO Pharma Ltd., Hyderabad, Formic acid, Methanol and ethyl acetate was procured from Merck Specialities Pvt. Ltd, Mumbai, India. Water used was collected from water purification systems (Milli Q, Milli
Pore, USA) installed in the laboratory. Pooled drug-free expired frozen human plasma (K2-EDTA as anticoagulant) was obtained froma Blood Bank, Hyderabad, was used during validation and study sample analysis. The plasma was stored into- $70 \pm 5{ }^{\circ} \mathrm{C}$.

\section{Standards and working solutions}

Calibration standard solutions

Stock solutions of pomalidomide and Fluconazole internal standard (IS) were prepared in methanol. Further dilutions were carried out in 50\% methanol. Calibration standards of nine concentration levels were prepared freshly by spiking drug-free plasma with pomalidomide stock solution to give the concentrations of 9.998, 25.241, 50.281, 150.438, $301.885,503.815,705.745,906.666$ and $1009.650 \mathrm{ng} / \mathrm{ml}$.

\section{Quality control standards}

Lowest quality control standards, Median quality control standards and highest quality control standards were prepared by spiking drug-free plasma with pomalidomide to give a solution containing $26.248,323.056$ and $807.640 \mathrm{ng} / \mathrm{ml}$ respectively. They were stored at-20 ${ }^{\circ} \mathrm{c}$ till the time analysed.

\section{Chromatographic conditions}

Chromatographic separation was performed on Xterra, RP18, $5 \mu$ (50 x $4.6 \mathrm{~mm}$ ), analytical column and the mobile phase was a mixture of $0.1 \%$ $(\mathrm{v} / \mathrm{v})$ formic acid in water to methanol at a ratio of 12:88, v/v. Injection volume was $10 \mu \mathrm{L}$. The flow rate was $0.50 \mathrm{ml} / \mathrm{min}$. Total analysis time of single injection was $2.0 \mathrm{~min}$. Column oven temperature and autosampler temperature was set to $30^{\circ} \mathrm{C}$ and $10^{\circ} \mathrm{C}$, respectively.

\section{Mass spectrometric conditions}

The LC eluent was split, and approximately $0.100 \mathrm{ml} / \mathrm{min}$ was introduced via electrospray ionisation using a Turbo Ion Spray interface set at $325^{\circ} \mathrm{C}$ to generate positive ions $[\mathrm{M}+\mathrm{H}]+$. The Mass spectrometric parameters were optimised as shown in table no 1. 
Table 1: Mass spectrometric conditions

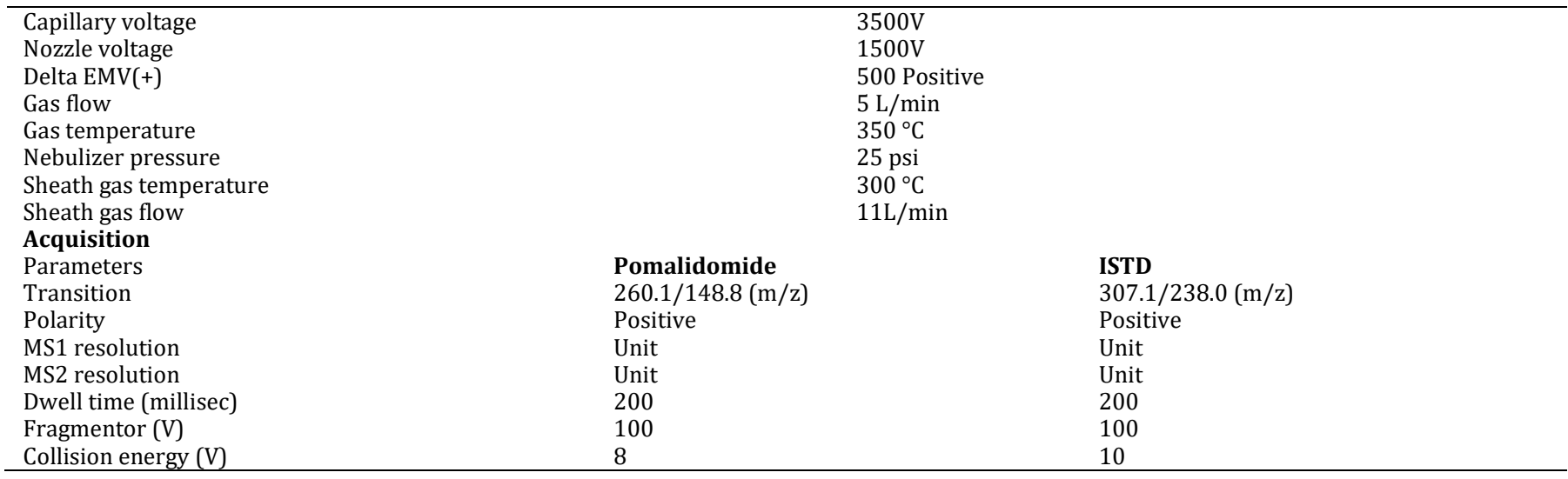

\section{Sample preparation method}

To $250 \mu \mathrm{l}$ of plasma, $50 \mu \mathrm{l}$ of ISTD $(1 \mu \mathrm{g} / \mathrm{ml})$ and $50 \mu \mathrm{l}$ of $0.1 \%$ formic acid was added and vortexed. The drug was extracted with $2.5 \mathrm{ml}$ of ethyl acetate, followed by centrifugation at $2000 \mathrm{rpm} / \mathrm{min}$ on a cooling centrifuge for $15 \mathrm{~min}$ at $4{ }^{\circ} \mathrm{C}$. The supernatant of $2 \mathrm{ml}$ was withdrawn and evaporated at $50{ }^{\circ} \mathrm{C} 15$ psi of nitrogen until dryness at LV evaporator. The residue was reconstituted with $500 \mu \mathrm{l}$ of mobile phase and respective samples were injected into the column.

\section{Validation}

\section{Specificity}

A solution containing $9.999 \mathrm{ng} / \mathrm{ml}$ was injected onto the column under optimised chromatographic conditions to show the separation of pomalidomide from impurities and plasma. The specificity of the method was checked for the interference from plasma.

\section{Linearity}

Spiked concentrations were plotted against peak area ratios of pomalidomide to the internal standard, and the best fit line was calculated. Wide range calibration was determined by solutions containing 9.998 to $1009.650 \mathrm{ng} / \mathrm{ml}$.

\section{Recovery studies}

The $\%$ mean recoveries were determined by measuring the responses of the extracted plasma Quality control samples at HQC, MQC and LQC against un-extracted Quality control samples at HQC, MQC and LQC.

\section{Precision and accuracy}

The between-run (Inter-day) accuracy and precision evaluation were assessed by the repeated analysis of human $\mathrm{K}_{3}$ EDTA plasma samples containing different concentrations of pomalidomide on separate occasions. A single run consisted of a calibration curve plus six replicates of the lower limit of quantitation, low, medium and high-quality control samples.

Within-run (Intraday) accuracy and precision evaluations were performed by analysing replicate concentrations of pomalidomide in human $\mathrm{K}_{3}$ EDTA plasma. The run consisted of a calibration curve plus a total of 24 spiked samples, six replicates of each of the LLOQ lower, medium and higher quality control samples.

\section{Matrix effect}

Blank plasma samples of 6 different human K3 EDTA plasma sources were processed and spiked with aqueous low-quality control and highquality control (post extraction addition) and analysed in a single run along with diluted pure standard at each concentration level.

\section{Ruggedness}

The ruggedness of the method was assessed by analysing a precision and accuracy batch using a different column, by the different analyst in another instrument.

\section{Stability studies}

\section{Short-term stock solution stability of pomalidomide}

Solutions of pomalidomide were prepared in methanol (Stability Samples) and were kept at room temperature for $6 \mathrm{~h} 30 \mathrm{~min}$. A freshly prepared solution of pomalidomide (Comparison Samples) and stability samples were diluted at approximately the same analyte concentration and analysed in a single run; analyte responses were used to determine $\%$ stability over time.

\section{Short-term stock solution stability of internal standard}

Solutions of internal standard (Fluconazole) were prepared in methanol (Stability Samples) and were kept at room temperature for $6 \mathrm{~h} 30 \mathrm{~min}$. A freshly prepared solution of internal standard (Comparison Samples) and stability samples were diluted at approximately the same analyte concentration and analyzed in a single run; Analyte responses were used to determine $\%$ stability over time.

\section{Freeze-thaw stability}

Samples were prepared at low and high-quality control levels, aliquoted and frozen at $-70^{\circ} \mathrm{C}$. Some of the aliquots of quality control samples were subjected to five freeze-thaw cycles (stability samples). A calibration curve and quality control samples were freshly prepared (Comparison Samples) and processed with 6 replicates of stability samples and analysed in a single run.

\section{Long-term stock solution stability of pomalidomide}

Solutions of Pomalidomide were prepared in methanol (Stability Samples) and were kept at refrigerator $\left(2-8^{\circ} \mathrm{C}\right)$ for $10 \mathrm{D} 02 \mathrm{H}$. A freshly prepared solution of pomalidomide (Comparison Samples) and stability samples were diluted at approximately the same analyte concentration and analysed in a single run.

\section{Long-term stock solution stability of internal standard}

Solutions of Internal standard were prepared in methanol (Stability Samples) and were kept at refrigerator $\left(2-8{ }^{\circ} \mathrm{C}\right)$ for $10 \mathrm{D} 02 \mathrm{H}$. A freshly prepared solution of internal standard (Comparison Samples) and stability samples were diluted at approximately the same analyte concentration and analysed in a single run

\section{RESULTS AND DISCUSSION}

The chromatography observed during the course of validation was acceptable and representative chromatograms of, LLOQ, LQC, MQC, HQC, internal standard (ISTD) and standard blank samples are shown in (fig. 1).

The method developed was validated for specificity, accuracy and precision, linearity, ruggedness and stability as per USFDA guidance [10-12]. The results of validating parameters are given below.

\section{Specificity}

Nine different lots of plasma were analysed to ensure that no endogenous interferences were present at the retention time of pomalidomide and fluconazole. Nine LLOQ $(9.999 \mathrm{ng} / \mathrm{ml})$ level samples along with plasma blank from the respective plasma lots were prepared and analysed. (table 2) shows results of specificity. In all plasma blanks, the response at the retention time of pomalidomide was less than $20 \%$ of LLOQ response, and at the retention time of IS, the response was less than $5 \%$ of mean IS response in LLOQ. The typical chromatogram of plasma blank and chromatogram of LLOQ was shown in (fig. 1). 

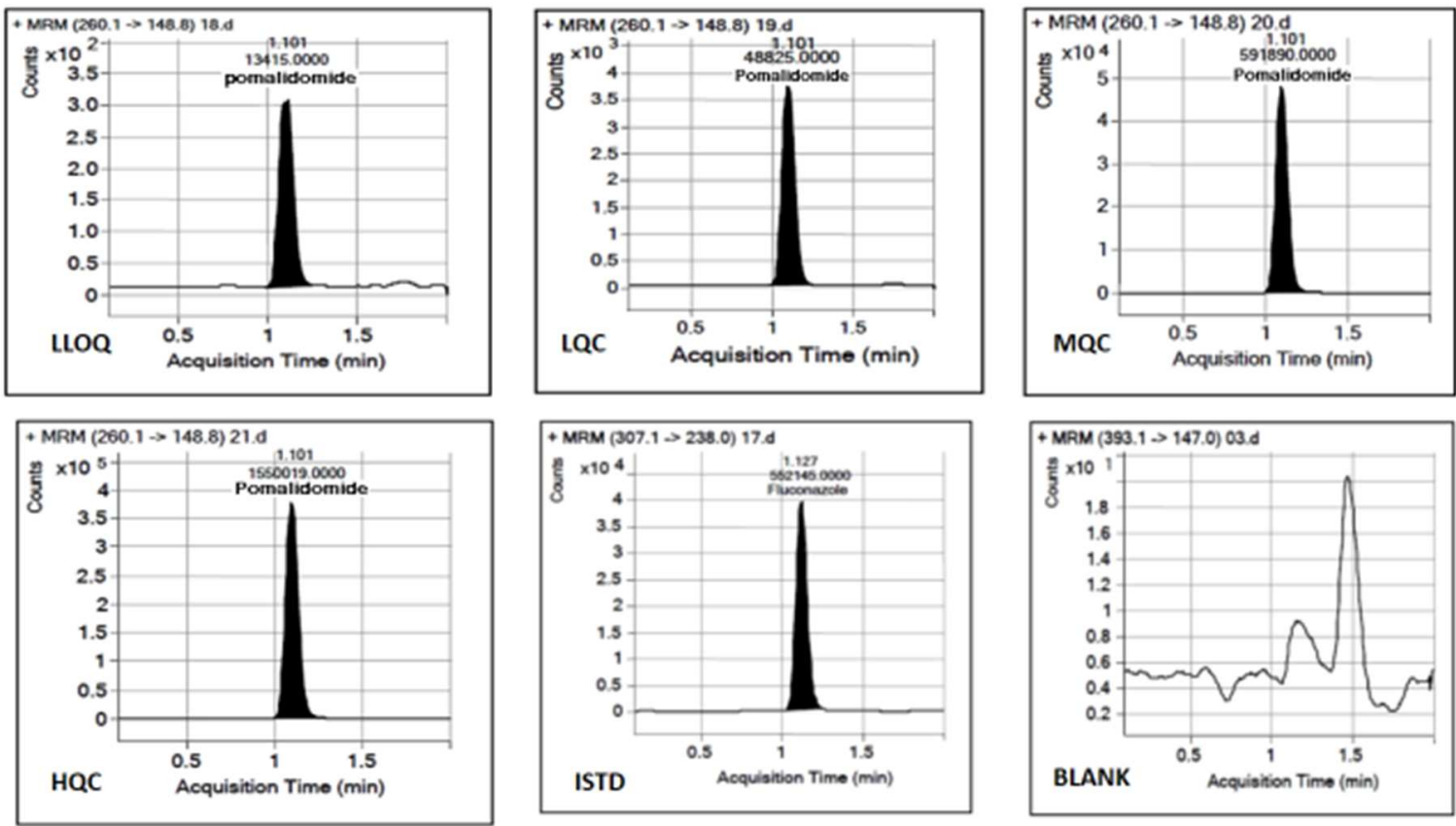

Fig. 1: Chromatograms of LLOQ, quality control samples, ISTD and blank matrix

Table 2: Results of specificity for pomalidomide and fluconazole (ISTD)

\begin{tabular}{llllll}
\hline & Analyte & & IS \\
\cline { 2 - 6 } & $\begin{array}{l}\text { Area of interfering } \\
\text { peak at RT of analyte }\end{array}$ & $\begin{array}{l}\text { Area observed for } \\
\text { extracted LLOQ }\end{array}$ & $\begin{array}{l}\text { \% Interference at } \\
\text { RT of analyte }\end{array}$ & $\begin{array}{l}\text { Area of interfering } \\
\text { Peak at RT of ISTD }\end{array}$ & $\begin{array}{l}\text { Area observed for } \\
\text { extracted ISTD }\end{array}$ \\
\hline 01 & 0 & 15286 & 0 & 0 & 575244 \\
\%T of ISTD & & 0 \\
02 & 0 & 13288 & 0 & 0 & 582214 \\
03 & 0 & 11110 & 0 & 0 & 578922 \\
04 & 0 & 11440 & 0 & 0 & 564562 \\
05 & 0 & 11402 & 0 & 0 & 558925 \\
06 & 0 & 11059 & 0 & 0 & 589001 \\
07 & 0 & 11215 & 0 & 0 & 591285 \\
08 & 0 & 11580 & 0 & 0 & 0 \\
09 & 0 & 12089 & 0 & 0 & 0 \\
Mean & 12052.111 & MEAN & 0 & 578862 \\
\hline
\end{tabular}

\section{Linearity}

The calibration curve (peak area ratio Vs Concentration) was linear over working a range of 9.998 to $1009.650 \mathrm{ng} / \mathrm{ml}$ with nine point calibration used for quantification by linear regression, shown in (fig. 2). The regression equation for the analysis was $\mathrm{Y}=0.0039 \mathrm{x}-0.0089$ with coefficient of correction $\left(\mathrm{r}^{2}\right)=0.99686$.

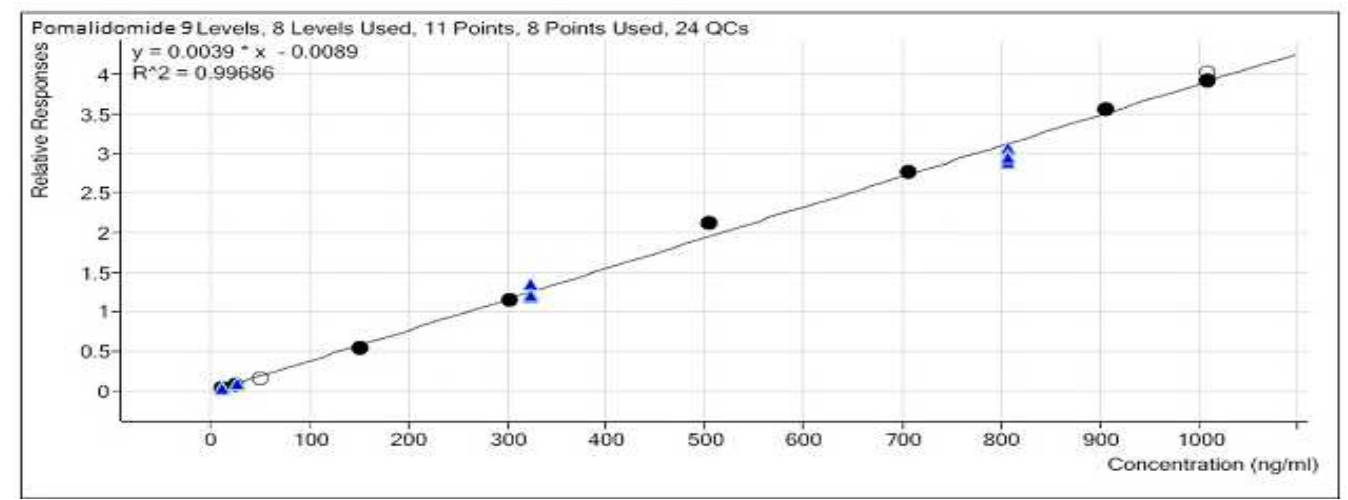

Fig. 3: Spiked concentrations (9.998 to $1009.650 \mathrm{ng} / \mathrm{ml})$ were plotted against calculated concentration Vs concentration with ten point calibration used for quantification by linear regression

\section{Recovery}

The \% mean recovery for pomalidomide in LQC, MQC and $\mathrm{HQC}$ was 50.68\%, 53.43\% and 57.49\% respectively (table 3). 
Table 3:\% Mean recovery of pomalidomide for $L Q C, M Q C$ and HQC

\begin{tabular}{|c|c|c|c|c|c|c|}
\hline & \multicolumn{2}{|l|}{ LQC 26.248ng/ml } & \multicolumn{2}{|c|}{ MQC $323.056 \mathrm{ng} / \mathrm{ml}$} & \multicolumn{2}{|c|}{ HQC $807.640 \mathrm{ng} / \mathrm{ml}$} \\
\hline & $\begin{array}{l}\text { Aqueous analyte } \\
\text { response }\end{array}$ & $\begin{array}{l}\text { Extracted analyte } \\
\text { response }\end{array}$ & $\begin{array}{l}\text { Aqueous analyte } \\
\text { response }\end{array}$ & $\begin{array}{l}\text { Extracted analyte } \\
\text { response }\end{array}$ & $\begin{array}{l}\text { Aqueous analyte } \\
\text { response }\end{array}$ & $\begin{array}{l}\text { Extracted analyte } \\
\text { response }\end{array}$ \\
\hline 01 & 240986 & 49902 & 2785844 & 599122 & 6694089 & 1549621 \\
\hline 02 & 245029 & 49079 & 2784946 & 595935 & 6765199 & 1550584 \\
\hline 03 & 244894 & 48906 & 2792062 & 593232 & 6782112 & 1564921 \\
\hline 04 & 243537 & 48828 & 2785487 & 591894 & 6835789 & 1571431 \\
\hline 05 & 240892 & 49190 & 2779585 & 593165 & 6838061 & 1568923 \\
\hline 06 & 238416 & 48789 & 2785210 & 598329 & 6870744 & 1573663 \\
\hline Mean & 242292.3 & 49115.6 & 2785522.3 & 595279.5 & 6797665.6 & 1563190.5 \\
\hline $\mathrm{SD}(+)$ & 2626.8 & 414.3 & 3963.6 & 2987.2 & 63952.7 & 10549.7 \\
\hline CV (\%) & 1.08 & 0.84 & 0.14 & 0.50 & 0.94 & 0.67 \\
\hline Conc. Factor & 250 & & 250 & & 250 & \\
\hline Mean Recovery & 50.68 & & 53.43 & & 57.49 & \\
\hline Global & 53.86 & & & & & \\
\hline Recovery & & & & & & \\
\hline
\end{tabular}

Intraday (within run) and inter-day (between run) precision and accuracy

The within-run coefficients of variation ranged between $1.47 \%$ and $4.57 \%$ for pomalidomide. The within-run percentages of nominal concentrations ranged between $97.95 \%$ and $107.58 \%$ for pomalidomide. Results are presented in table 4.

The between-run coefficients of variation ranged between $2.88 \%$ and $4.22 \%$ for pomalidomide. The between-run percentages of nominal concentrations ranged between $99.41 \%$ and $106.97 \%$ for pomalidomide. Results are presented in table 5.

\section{Matrix effect}

The percentage matrix effect of analyte was found to be- 0.25 and 2.74 for pomalidomide for low and high-quality control samples. Results are presented in table 6.

\section{Ruggedness}

The coefficients of variation ranged between $1.32 \%$ and $4.03 \%$ for pomalidomide. The percentages of nominal concentrations ranged between $101.06 \%$ and $110.08 \%$ for pomalidomide. Results are presented in table 7.

Table 4: Intraday precision and accuracy of quality control standard

\begin{tabular}{|c|c|c|c|c|c|c|c|c|}
\hline \multirow[t]{2}{*}{ S. No. } & \multicolumn{2}{|c|}{ LLOQ $9.999 \mathrm{ng} / \mathrm{ml}$} & \multicolumn{2}{|c|}{ LQC 26.248ng/ml } & \multicolumn{2}{|c|}{ MQC $323.056 \mathrm{ng} / \mathrm{ml}$} & \multicolumn{2}{|c|}{ HQC $807.640 \mathrm{ng} / \mathrm{ml}$} \\
\hline & $\begin{array}{l}\text { Conc. found } \\
\text { (ng/ml) }\end{array}$ & $\begin{array}{l}\text { \% nominal } \\
\text { Conc }\end{array}$ & $\begin{array}{l}\text { Conc. found } \\
\text { (ng/ml) }\end{array}$ & $\begin{array}{l}\text { \% nomi } \\
\text { Conc nal }\end{array}$ & $\begin{array}{l}\text { Conc. found } \\
\text { (ng/ml) }\end{array}$ & $\begin{array}{l}\text { \% nominal } \\
\text { Conc }\end{array}$ & $\begin{array}{l}\text { Conc. found } \\
\text { (ng/ml) }\end{array}$ & $\begin{array}{l}\text { \% nominal } \\
\text { Conc }\end{array}$ \\
\hline 1 & 10.705 & 107.06 & 28.081 & 106.98 & 315.669 & 97.71 & 762.368 & 94.39 \\
\hline 2 & 10.569 & 105.70 & 27.895 & 106.27 & 355.681 & 110.10 & 782.178 & 96.85 \\
\hline 3 & 10.411 & 104.12 & 27.857 & 106.13 & 318.659 & 98.64 & 775.543 & 96.03 \\
\hline 4 & 11.487 & 114.88 & 27.942 & 106.45 & 324.372 & 100.41 & 810.934 & 100.41 \\
\hline 5 & 10.61 & 106.11 & 27.841 & 106.07 & 317.699 & 98.34 & 805.069 & 99.68 \\
\hline 6 & 10.758 & 107.60 & 28.915 & 110.16 & 327.842 & 101.48 & 810.606 & 100.37 \\
\hline $\mathrm{N}$ & 6 & 6 & 6 & 6 & 6 & 6 & 6 & 6 \\
\hline Mean & 10.757 & 107.58 & 28.089 & 107.01 & 326.654 & 101.11 & 791.116 & 97.95 \\
\hline $\operatorname{SD}( \pm)$ & 0.38 & & 0.41 & & 14.93 & & 20.57 & \\
\hline CV(\%) & 3.51 & & 1.47 & & 4.57 & & 2.60 & \\
\hline
\end{tabular}

Table 5: Inter day precision and accuracy of quality control standard

\begin{tabular}{|c|c|c|c|c|c|c|c|c|}
\hline \multirow[t]{2}{*}{ Batch ID } & \multicolumn{2}{|c|}{ LLOQ $9.999 \mathrm{ng} / \mathrm{ml}$} & \multicolumn{2}{|c|}{ LQC 26.248ng/ml } & \multicolumn{2}{|c|}{ MQC $323.056 \mathrm{ng} / \mathrm{ml}$} & \multicolumn{2}{|c|}{ HQC 807.640ng/ml } \\
\hline & $\begin{array}{l}\text { Conc. found } \\
\text { (ng/ml) }\end{array}$ & $\begin{array}{l}\text { \% nominal } \\
\text { conc }\end{array}$ & $\begin{array}{l}\text { Conc. found } \\
\text { (ng/ml) }\end{array}$ & $\begin{array}{l}\text { \% nominal } \\
\text { conc }\end{array}$ & $\begin{array}{l}\text { Conc. found } \\
\text { (ng/ml) }\end{array}$ & $\begin{array}{l}\text { \% nominal } \\
\text { conc }\end{array}$ & $\begin{array}{l}\text { Conc. found } \\
\text { (ng/ml) }\end{array}$ & $\begin{array}{l}\text { \% nominal } \\
\text { conc }\end{array}$ \\
\hline & 10.705 & 107.06 & 28.081 & 106.98 & 315.669 & 97.71 & 762.368 & 94.39 \\
\hline & 10.569 & 105.70 & 27.895 & 106.27 & 355.681 & 110.10 & 782.178 & 96.85 \\
\hline \multirow{6}{*}{$\begin{array}{l}\text { PandA- } \\
01\end{array}$} & 10.411 & 104.12 & 27.857 & 106.13 & 318.659 & 98.64 & 775.543 & 96.03 \\
\hline & 11.487 & 114.88 & 27.942 & 106.45 & 324.372 & 100.41 & 810.934 & 100.41 \\
\hline & 10.610 & 106.11 & 27.841 & 106.07 & 317.699 & 98.34 & 805.069 & 99.68 \\
\hline & 10.758 & 107.60 & 28.915 & 110.16 & 327.842 & 101.48 & 810.606 & 100.37 \\
\hline & 10.322 & 103.23 & 27.867 & 106.17 & 311.270 & 96.35 & 762.021 & 94.35 \\
\hline & 10.385 & 103.86 & 26.741 & 101.88 & 355.184 & 109.95 & 783.091 & 96.96 \\
\hline \multirow{6}{*}{$\begin{array}{l}\text { PandA- } \\
02\end{array}$} & 10.609 & 106.10 & 26.569 & 101.22 & 315.344 & 97.61 & 762.157 & 94.37 \\
\hline & 10.896 & 108.97 & 27.498 & 104.76 & 312.676 & 96.79 & 798.395 & 98.86 \\
\hline & 10.268 & 102.69 & 27.581 & 105.08 & 313.590 & 97.07 & 786.741 & 97.41 \\
\hline & 10.307 & 103.08 & 27.235 & 103.76 & 317.332 & 98.23 & 793.101 & 98.20 \\
\hline & 10.729 & 107.30 & 28.810 & 109.76 & 330.628 & 102.34 & 775.171 & 95.98 \\
\hline & 10.867 & 108.69 & 28.880 & 110.03 & 318.223 & 98.50 & 838.267 & 103.79 \\
\hline \multirow{4}{*}{$\begin{array}{l}\text { PandA- } \\
03\end{array}$} & 10.309 & 103.10 & 29.561 & 112.62 & 326.177 & 100.97 & 830.304 & 102.81 \\
\hline & 10.321 & 103.22 & 29.126 & 110.97 & 328.816 & 101.78 & 874.482 & 108.28 \\
\hline & 10.805 & 108.06 & 29.018 & 110.55 & 327.572 & 101.40 & 854.598 & 105.81 \\
\hline & 10.443 & 104.44 & 27.968 & 106.55 & 327.423 & 101.35 & 846.592 & 104.82 \\
\hline $\mathrm{N}:$ & 18 & 18 & 18 & 18 & 18 & 18 & 18 & 18 \\
\hline Mean: & 10.600 & 106.01 & 28.077 & 106.97 & 324.675 & 100.50 & 802.868 & 99.41 \\
\hline $\operatorname{SD}( \pm)$ : & 0.31 & & 0.83 & & 12.76 & & 33.89 & \\
\hline CV (\%): & 2.88 & & 2.95 & & 3.93 & & 4.22 & \\
\hline
\end{tabular}


Table 6: Results of matrix effect obtained by preparing LQC and HQC with six different lots of plasma

\begin{tabular}{lllll}
\hline S. No. & AQS LQC response & PEX LQC response & AQS HQC response \\
\hline 1 & 195688 & 203204 & 5680638 & PEX HQC response \\
2 & 200736 & 197892 & 5694436 & 5635662 \\
3 & 200626 & 197423 & 5637040 & 5694225 \\
4 & 198973 & 198785 & 5647571 & 5355785 \\
5 & 200778 & 199084 & 5680208 & 5716531 \\
6 & 201077 & 198505 & 5655245 & 5772353 \\
Mean & 199646.333 & 199148.833 & 5665856.333 \\
SD & 2078.29 & 2076.23 & 22443.71 & 5821364 \\
\%CV & 1.04 & 1.04 & 0.4 & 266171.21 \\
\%ME & -0.25 & & 2.74 & 4.57 \\
\hline
\end{tabular}

Table 7: Results of ruggedness

\begin{tabular}{|c|c|c|c|c|c|c|c|c|}
\hline \multirow[t]{2}{*}{ S. No. } & \multicolumn{2}{|c|}{ LLOQ $9.999 \mathrm{ng} / \mathrm{ml}$} & \multicolumn{2}{|c|}{ LQC 26.248ng/ml } & \multicolumn{2}{|c|}{ MQC $323.056 \mathrm{ng} / \mathrm{ml}$} & \multicolumn{2}{|c|}{ HQC $807.640 \mathrm{ng} / \mathrm{ml}$} \\
\hline & $\begin{array}{l}\text { Conc. found } \\
\text { (ng/ml) }\end{array}$ & $\begin{array}{l}\text { \% nominal } \\
\text { conc }\end{array}$ & $\begin{array}{l}\text { Conc. found } \\
(\mathrm{ng} / \mathrm{ml})\end{array}$ & $\begin{array}{l}\% \\
\text { nominal conc }\end{array}$ & $\begin{array}{l}\text { Conc. found } \\
(\mathrm{ng} / \mathrm{ml})\end{array}$ & $\begin{array}{l}\text { \% nominal } \\
\text { conc }\end{array}$ & $\begin{array}{l}\text { Conc. found } \\
(\mathrm{ng} / \mathrm{ml})\end{array}$ & $\begin{array}{l}\text { \% nominal } \\
\text { conc }\end{array}$ \\
\hline 1 & 10.729 & 107.30 & 28.810 & 109.76 & 330.62 & 102.34 & 775.171 & 95.98 \\
\hline 2 & 10.867 & 108.69 & 28.880 & 110.03 & 318.22 & 98.50 & 838.267 & 103.79 \\
\hline 3 & 10.309 & 103.10 & 29.561 & 112.62 & 326.17 & 100.97 & 830.304 & 102.81 \\
\hline 4 & 10.321 & 103.22 & 29.126 & 110.97 & 328.81 & 101.78 & 874.482 & 108.28 \\
\hline 5 & 10.805 & 108.06 & 29.018 & 110.55 & 327.57 & 101.40 & 854.598 & 105.81 \\
\hline 6 & 10.443 & 104.44 & 27.968 & 106.55 & 327.42 & 101.35 & 846.592 & 104.82 \\
\hline $\mathrm{N}$ & 6 & 6 & 6 & 6 & 6 & 6 & 6 & 6 \\
\hline Mean & 10.579 & 105.80 & 28.894 & 110.08 & 326.47 & 101.06 & 836.569 & 103.58 \\
\hline $\mathrm{SD}( \pm)$ & 0.25 & & 0.53 & & 4.31 & & 33.69 & \\
\hline CV $(\%)$ & 2.37 & & 1.82 & & 1.32 & & 4.03 & \\
\hline
\end{tabular}

\section{Stability studies}

\section{Short-term stock solution stability of pomalidomide}

Pomalidomide is found to be stable in methanol for $6 \mathrm{~h} 30 \mathrm{~min}$ at room temperature with a \% stability of $99.01 \%$. Results are presented in table 8 .

\section{Short-term stock solution stability of internal standard}

The internal standard is found to be stable in methanol for $6 \mathrm{~h} 30$ min at room temperature with a \% stability of $99.15 \%$. Results are presented in table 9 .

\section{Freeze-thaw stability}

Pomalidomide is found to be stable in human $\mathrm{K}_{3}$ EDTA plasma after five freeze-thaw cycles at- $70{ }^{\circ} \mathrm{C}$ with coefficients of variation of
$3.27 \%$ (LQC) and $3.86 \%$ (HQC) for pomalidomide, and the percentages of nominal concentrations for pomalidomide were found to be $103.17 \%$ (LQC) and $101.23 \%$ (HQC). Results are presented in table 10.

\section{Long-term stock solution stability of pomalidomide}

Pomalidomide is found to be stable in methanol $10 \mathrm{D} 02 \mathrm{H}$ at refrigerator $\left(2-8^{\circ} \mathrm{C}\right)$ with a $\%$ stability of $98.49 \%$ for pomalidomide. Results are presented in table 11.

\section{Long-term stock solution stability of internal standard}

The internal standard is found to be stable in methanol $10 \mathrm{D} 02 \mathrm{H}$ at refrigerator $\left(2-8{ }^{\circ} \mathrm{C}\right)$ with a $\%$ stability of $97.74 \%$. Results are presented in table 12 .

Table 8: Short-term stock solution stability of analyte

\begin{tabular}{lll}
\hline S. No. & Analyte & CS \\
\cline { 2 - 3 } & SS & 2606664 \\
\hline 1 & 2564444 & 2616699 \\
2 & 2597482 & 2630379 \\
3 & 2606795 & 2627041 \\
4 & 2611068 & 2630048 \\
6 & 2598633 & 2629280 \\
Mean & 2608998 & 2623351.833 \\
SD & 2597903.333 & 9651.08 \\
\% Stability & 17295.66 & 0.37 \\
\hline
\end{tabular}

Table 9: Short-term stock solution stability of internal standard

\begin{tabular}{lll}
\hline S. No. & ISTD & Comparison solution \\
\cline { 2 - 3 } & Stability solution & 2521525 \\
\hline 1 & 2504198 & 2524682 \\
2 & 2510082 & 2537401 \\
3 & 2498215 & 2519696 \\
4 & 2487925 & 2504040 \\
5 & 2512367 & 2526432 \\
Mean & 2491004 & 2522296.000 \\
SD & 2500631.833 & 10877.47 \\
\%CV & 9997.37 & 0.43 \\
\hline
\end{tabular}


Table 10: Freeze-thaw stability at-70 ${ }^{\circ} \mathrm{C}$

\begin{tabular}{|c|c|c|c|c|}
\hline \multirow[t]{4}{*}{ S. No. } & \multicolumn{2}{|c|}{ Freshly spiked } & \multicolumn{2}{|c|}{ Freeze-thaw } \\
\hline & LQC & HQC & LQC & HQC \\
\hline & \multicolumn{2}{|c|}{ Nominal Con (ng/ml) } & \multicolumn{2}{|c|}{ Nominal Con (ng/ml) } \\
\hline & 26.249 & 807.648 & 26.248 & 807.64 \\
\hline 1 & 28.019 & 791.749 & 29.380 & 801.458 \\
\hline 2 & 27.816 & 767.862 & 30.051 & 839.017 \\
\hline 3 & 27.327 & 789.495 & 28.055 & 824.962 \\
\hline 4 & 27.830 & 821.854 & 27.867 & 754.842 \\
\hline 5 & 27.819 & 842.104 & 28.198 & 791.864 \\
\hline 6 & 27.272 & 770.159 & 27.791 & 830.043 \\
\hline Mean & 27.680 & 797.204 & 28.557 & 807.031 \\
\hline SD & 0.31 & 29.34 & 0.93 & 31.17 \\
\hline$\% \mathrm{CV}$ & 1.10 & 3.68 & 3.27 & 3.86 \\
\hline$\%$ stability & & & 103.17 & 101.23 \\
\hline
\end{tabular}

Table 11: Long-term stock solution stability of analyte

\begin{tabular}{lll}
\hline S. No. & Analyte & CS \\
\cline { 2 - 3 } & SS & 2314048 \\
1 & 2280682 & 2311173 \\
2 & 2287758 & 2307848 \\
3 & 2291699 & 2312386 \\
4 & 2288329 & 2324564 \\
5 & 2300006 & 2353235 \\
6 & 2287308 & 2314048 \\
Mean & 2280682 & 16985.98 \\
SD & 6355.03 & 0.73 \\
\%CV & 0.28 & \\
\hline stability & 98.49 & \\
\hline
\end{tabular}

Table 12: Long-term stock solution stability of internal standard

\begin{tabular}{lll}
\hline S. No. & ISTD & Comparison solution \\
\cline { 2 - 3 } & Stability solution & 2520014 \\
\hline 1 & 2458845 & 2531462 \\
2 & 2448795 & 2512650 \\
3 & 2431526 & 2526423 \\
4 & 2484415 & 2513284 \\
5 & 2478462 & 2500186 \\
6 & 2460025 & 2517336.5 \\
Mean & 2460344.7 & 11151.5822 \\
SD & 19359.133 & 0.44 \\
\hline C stability & 0.79 & \\
\hline
\end{tabular}

\section{CONCLUSION}

Chromatographic separation was achieved on Xterra, $\mathrm{RP}_{18}, 5 \mu(50 \mathrm{x}$ $4.6 \mathrm{~mm}$ ) column using a mixture of $0.1 \%(\mathrm{v} / \mathrm{v})$ formic acid in water to methanol at a ratio of $12: 88, \mathrm{v} / \mathrm{v}$ as the mobile phase. The drug was extracted with $2.5 \mathrm{ml}$ of ethyl acetate. The specificity of the method was checked for the interference from plasma. The calibration curve (peak area ratio Vs Concentration) was linear over working a range of 9.998 to $1009.650 \mathrm{ng} / \mathrm{ml}$ with nine point calibration used for quantification by linear regression. The $\%$ mean recovery for pomalidomide in LQC, MQC and HQC was $50.68 \%, 53.43 \%$ and $57.49 \%$ respectively. The within-run coefficients of variation ranged between $1.47 \%$ and $4.57 \%$ for pomalidomide. The between-run coefficients of variation ranged between $2.88 \%$ and $4.22 \%$ for pomalidomide. The percentage matrix effect of analyte was found to be- 0.25 and 2.74 for pomalidomide for low and high-quality control samples. The stability test was performed to assess the long term and short term stability of sofosbuvir sample solutions, internal standard solutions. The developed method was validated for the quantitative determination of sofosbuvir from plasma was simple, rapid, specific, sensitive, accurate and precise. Hence, the method is quite suitable to detect the drug from plasma samples of human volunteers.

\section{ACKNOWLEDGEMENT}

I am also grateful to my scholars and my friends for their kind help from time to time at each and every step of my project work.

\section{CONFLICT OF INTERESTS}

Declared none

\section{REFERENCES}

1. Lacy MQ, McCurdy AR. Pomalidomide. Blood 2013;122:2305-9.

2. https://pubchem.ncbi.nlm.nih.gov/compound/134780. [Last accessed on 12 Jun 2016]

3. Amato D, Robert J, Loughnan, Michael S, Flynn, Evelyn, et al. Thalidomide is an inhibitor of angiogenesis. Proc Natl Acad Sci USA 1994;91:4082-5.

4. Amato D, Lentzsch R, Anderson S, Rogers KCMS. Mechanism of action of thalidomide and 3-aminothalidomide in multiple myeloma. Semin Oncol 2001;28:597-601.

5. Teo SK, Chen Y, Muller GW, Chen RS, Thomas SD, Stirling DI, et al. Chiral inversion of the second generation IMiD CC- 4047 (ACTIMID) in human plasma and phosphate-buffered saline. Chirality 2003;15:348-51.

6. Meiler SE, Wade M, Kutlar F, Yerigenahally SD, Xue Y, Moutouhde Parseval LA, et al. Pomalidomide augments fetal hemoglobin production without the myelosuppressive effects of hydroxyurea in transgenic sickle cell mice. Blood 2011;118:1109-12.

7. Hoffmann M, Kasserra C, Reyes J, Schafer P, Kosek J, Capone L, et al. Absorption, metabolism and excretion of [14C] pomalidomide in humans following oral administration. Cancer Chemother Pharmacol 2013;71:489-501. 
8. Iqbal M, Ezzeldin E, Al-Rashood KA, Shakeel F. A validated UPLC-MS/MS assay using negative ionisation mode for highthroughput determination of pomalidomide in rat plasma. J Chromatogr B: Anal Technol Biomed Life Sci 2015;983:76-82.

9. Analytical Procedures and Methods Validation for Drugs and Biologics Guidance for Industry. U. S. Department of Health and Human Services, Food and Drug Administration Center for Drug Evaluation and Research (CDER), Center for Biologics Evaluation and Research (CBER); 2015.

10. Sindhusri M, Swetha T, Ramadevi A, Ashok Kumar A. A novel rapid rp-hplc method development and validation for the quantitative estimation of balofloxacin in tablets. Int J Pharm Pharm Sci 2014;7:319-22.
11. Raveendra Babu G, Lakshmana Rao A, Venkateswara Rao I. A rapid RP-HPLC method development and validation for the quantitative estimation ribavirin in tablets. Int J Pharm Pharm Sci 2014:7:60-3.

12. Srinidhi M, Mushabbar Basha MD, V Raj Kumar, Rajendra Kumar J. Stability indicating RP-HPLC method development and validation for the estimation of sumatriptan in bulk and pharmaceutical dosage form. J Appl Pharm Sci 2016;6:20-5.

\section{How to cite this article}

- D Atul Vasanth, B Rajkamal. A UPLC-MS/MS method development and validation for the estimation of pomalidomide from human plasma. Int J Appl Pharm 2017;9(1):37-43. 